\title{
The troublesome guidance towards academic literacy
}

\author{
Best practice article \\ Marit Greek*, Kari Mari Jonsmoen \\ OsloMet - Oslo Metropolitan University
}

\begin{abstract}
The present article draws on the findings of a qualitative study carried out in two Norwegian upper secondary schools (Greek \& Jonsmoen, 2016; Jonsmoen \& Greek, 2017). According to research findings, students having graduated from upper secondary school ought to be sufficiently prepared for meeting the demands of higher education, and for further developing their textual competences within the discipline specific contexts. Nevertheless, according to lecturers, librarians and experts in academic writing in higher education, students are still in need of guidance in their textual work. The question is how higher education can establish and implement a coherent and integrated writing support for students. The article discusses writing support in light of writing theory and literacy research. According to international research findings, writing in higher education is part of a disciplinary discourse, and disciplinary literacy skills are essential for building textual competences within a specific disciplinary community. Thus, the essential factors in guiding students in their writing process are genre conventions, text organization and argumentation. However, the students also need guidance in searching relevant literature as well as dealing with sources in a correct manner. The article emphasizes the significance of textual knowledge when guiding the students in higher education. However, librarians and lecturers possess different knowledge, and are part of different disciplinary discourses. There is therefore a need for debating what guidance in writing is to be, and how lecturers and librarians can complement each other and together offer constructive and relevant guidance.
\end{abstract}

Keywords: academic writing, higher education, library, akademisk skriving, skriveopplæring, bibliotek, akademisk dannelse

*Contact:

Marit Greek

e-mail: maritgr@oslomet.no 


\section{Innledning}

Antall bøker som publiseres om skriving i høyere utdanning, etterspørsel etter kurs i akademisk skriving og etablering av skrivesentre ved høgskoler og universitet, forteller om et stort behov for skrivehjelp blant studenter. Studentene skal lære et nytt fag, og de skal lære å uttrykke sin fagforståelse i skriftlige tekster innenfor gitte kriterier. I mange tilfeller er veiledning i fagskriving underveis i skriveprosessen avgjørende for hvilke resultater studentene oppnår. Men hvordan bør skriveveiledningen være? Hvilken forkunnskap trenger studentenes ulike veiledere, hvem skal bidra med hva og når? For å svare på disse spørsmålene må vi vite hvilken tekstkyndighet studentene har med seg fra videregående skole, og vi må ta i betraktning hva forskning på studenters skriving forteller oss. Artikkelen løfter fram faktorer som er viktige i arbeidet med å etablere en god praksis for skriveveiledning. Begrepet «veiledning» vil i det følgende brukes både om undervisning og veiledning, og «veileder» brukes, dersom noen annet ikke er presisert, om alle som underviser og veileder studenter i skriving. Det vil si både lærere, bibliotekarer og skrivepedagoger. I denne artikkelen er lærer en fellesbetegnelse for alle som underviser studenter i det faget studentene studerer.

Artikkelen er tredelt. Den første delen tar utgangspunkt i en kvalitativ, deskriptiv studie som ser på hva norskfaget i studieforberedende utdanningsprogram vektlegger når det gjelder akademisk tekstkyndighet og hvilken tekstkyndighet elevene viser i sitt avsluttende skoleår. I artikkelens andre del rettes søkelyset mot studenters tekstkyndighet og funn fra to studier gjennomført blant studenter i høyere utdanning. I artikkelens siste del diskuteres funnene fra videregående skole og høyere utdanning, og det konkluderes med hva god skriveveiledning i høyere utdanning kan være. Artikkelen avsluttes med konkrete spørsmål som må avklares for at en helhetlig og systematisk veiledning i skriving skal bli en realitet og med en påstand om behov for mer kompetanse blant de som veileder studentene i studentenes skrivearbeid.

I kjølvannet av Kvalitetsreformen (St.meld. nr. 27 (2000-2001)) har skriftlige arbeider fått en sentral plass i høyere utdanning. Studenter skriver i teoretiske studier og de skriver i praktiske studier. Hver fagdisiplin har sin språklige praksis, sin egen terminologi og sine egne tekstsjangre. Å lære et fag, sier Hoel (2008a), «inneber å lære fagspråk, omgrep, sjangrar og tekstkonvensjoner [...] og såleis bli medlem av ein tekstkultur» (p. 19). For å lykkes i studier må studentene beherske tekstkulturen i det faget de studerer, de må ha fagrelevant tekstkyndighet. Studenter med studiekompetanse fra norsk videregående skole, skal i henhold til læreplanen i norsk), ha fått opplæring i fagskriving (Utdanningsdirektoratet, udatert a) og er således forberedt på de kravene som stilles til fagskriving i høyere utdanning. Å være forberedt betyr imidlertid ikke at de mestrer fagskrivingen til det fulle. Studentene møter studiet med sin tekstkyndighet som må videreutvikles og gjøres relevant i den tekstkulturen som gjelder for det faget de studerer. For å utvikle relevant og tilstrekkelig tekstkyndighet trenger studentene, ifølge Lindberg og Sandblom (2013), å kunne se sin egen skriveprosess og egne og andres fagspesifikke tekster i et metaperspektiv, og til det trenger de veiledning. Studentene har dessuten behov for hjelp til å utvikle strategier for å utvikle tekstkyndighet $\mathrm{i}$ en faglig sammenheng, blant annet strategier for å lese faglitteratur og formidle fagstoffet i samsvar med de kravene studiet stiller.

Skriveforskere, både nasjonalt og internasjonalt, ser tekstkyndighet som en integrert del av ethvert fag, og mener derfor at ans varet for å føre studentene inn i den rådende tekstkulturen ligger på fagets lærere (Hoel, 2008b; Hunter \& Tse, 2013; Samara \& Dysthe, 2006; Skjelbred, 2012; Wingate, 2012a; Wingate, Andon, \& Cogo, 2011; Wingate \& Tribble, 2012; Øgreid \& Hertzberg, 2009). I grunn- og videregående skole er denne kunnskapen tatt til etterretning gjennom Kunnskapsløftet (KL06), og i planverket for norsk grunn- og videregående skole er skriving i alle fag vektlagt: «Undervisning i lesing og skriving kan ikke lenger isoleres fra det 
å lære et fag og det å lære å uttrykke seg i faget. Læring er å bli stadig mer fortrolig med fagets tekstkultur» (Utdanningsdirektoratet, udatert b). Imidlertid avdekker evalueringen av KL06, at lærerne i de ulike fagene, med unntak av norskfaget, likevel ikke vektlegger fagets tekstkultur (Hertzberg \& Roe, 2016; Øgreid \& Hertzberg, 2009; Sivesind, 2013). Studier i høyere utdanning viser det samme (Greek \& Jonsmoen, 2016; Hunter \& Tse, 2013; Jonsmoen \& Greek, 2016; Wingate et al., 2011). Lærere i høyere utdanningen ser det ikke som sin oppgave å gi eksplisitt veiledning i fagdisiplinens teksttradisjoner. Dels mener lærerne at undervisning i fagskriving vil ta verdifull tid fra fagspesifikk undervisning, dels føler de seg ikke kompetente til å gi en slik opplæring (Jonsmoen \& Greek, 2016). Veiledning i fagskrivingens enkelte deler delegeres derfor til andre, for eksempel til bibliotekarer og skrivepedagoger utenfor fakultetet. Mye tyder altså på at tilbudet studentene får i forbindelse med fagskriving strider imot det forskningen sier er god skriveveiledning.

\section{Elevers tekstkyndighet}

Den tekstkyndigheten studenter har når de starter sine studier i høyere utdanning, er i stor grad formet av tekstarbeidet i grunn- og videregående skole. Kunnskap om hva norsklærerne i videregående skole vektlegger i sin undervisning og veiledning og hvordan undervisningens innhold manifesterer seg i elevenes tekstforståelse og skriving, er derfor relevant for alle som skal introdusere nye studenter for skriving i studiet.

I kompetansemålene for skriftlig kommunikasjon etter $\mathrm{Vg} 3$ - studieforberedende utdanningsprogram står det at elevene skal kunne orientere seg i store mengder tekst av ulik kompleksitet og velge ut, sammenfatte og vurdere relevant informasjon. De tekstene elevene skriver, skal ha en klar hensikt, en logisk struktur og saklig argumentasjon. Elevene skal kunne uttrykke seg med et presist og nyansert ordforråd og mestre språklige formkrav, bruke kilder på en kritisk og etterprøvbar måte og beherske digital kildehenvisning (Utdanningsdirektoratet, udatert b). Målene i videregående skole samsvarer i stor grad med de formelle krav som stilles til skriftlige tekster i høyere utdanning. Rienecker og Jørgensen (2013) har sett på hva som karakteriserer gode oppgaver i høyere utdanning, og de konkluderer med at bruk av fagkunnskap og at teksten innfrir formelle krav er blant de kvaliteter som må være til stede.

Studien i videregående skole ble gjennomført som et etnografisk feltarbeid, skoleåret 2014/2015. Vi deltok i samtlige norsktimer ved to videregående skoler, i elevenes avsluttende skoleår og vekslet mellom å være observatører, deltakere og intervjuere. Vi har lest gjennom 310 elevtekster, og 46 av elevene ga oss tillatelse til å analysere tekstene de skrev. Funnene viser at elevene mener de er forberedt på de tekstkrav de vil møte i framtidige studier. Samtidig viser analyse av tekstene at tekstkyndigheten deres er preget av overflatekunnskap, og at det er en diskrepans mellom hva de vet om tekst og hvordan de selv skriver (Greek \& Jonsmoen, 2016; Jonsmoen \& Greek, 2017). En tilsvarende studie gjort blant svenske ungdommer på videregående skole og lærerstudenter ved en svensk høgskole, avdekket at både elever og studenter har mangelfulle ferdigheter når det gjelder å strukturere og forme et faglig resonnement og å begrunne koplingen mellom fakta og konklusjon (Lindberg \& Sandblom, 2013). Funnene samsvarer med funn fra vår studie. Også elever i norsk videregående skole har problemer med å organisere innholdet innad i avsnittene slik at resonnementet kommer klart fram og teksten framstår som velorganisert og helhetlig. En av informantene i studien forteller: «Jeg er flink til å kanskje begynne å blande i avsnittene, at jeg putter på flere ting og så kommer det igjen i den andre og så blir det gjentakelser» (Greek \& Jonsmoen, 2016, s. 263).

Rienecker og Stray Jørgensen (2013) viste i sin studie, at anvendelse av fagkunnskap er vesentlig i en studentoppgave. For å kunne argumentere saklige og presist innen et fag, må både 
studenter og elever ha tilstrekkelig faglig forståelse til å trekke fram sentrale faglige momenter. Da må de: «kunne tolke, produsere og reflektere over tekster» (Skjelbred \& Veum, 2013, s. 18). $\AA$ tolke og reflektere over tekster krever metaforståelse og kontekstbevissthet. For å kunne utvikle en slik kompetanse, må elevene ifølge Penne (2013, p. 47) «lære å tolke, det vil si å holde eget syn tilbake til man har fors økt å forstå den andres perspektiv». Denne tekstkyndigheten er grunnleggende for å forstå og skrive fagtekster, og den kan bare opparbeides ved å lese. Imidlertid er mange av elevene på videregående skole svake lesere (Greek \& Jonsmoen, 2016; Jonsmoen \& Greek, 2017; Lødding og Aamodt 2015). Elevene finner det vanskelig å lese lengre, sammenhengende tekster, til tross for at lesing er sterkt vektlagt i læreplanen (Utdanningsdirektoratet, udatert a). I stedet for å ta tak i utfordringene og trene opp leseferdighetene sine, omgår de problemet ved å lese «korte utdrag fra lærebøker og internettekster, og av og til ble korte kronikker lest i forbindelse med skriftlige oppgaver», (Greek \& Jonsmoen, 2016, s 12).

Likevel, de fleste elevene har ved slutten av videregående skole, relevant tekstkyndighet for studier. I rapporten Studieforberedt etter studieforberedende, konkluderer Lødding og Aamodt (2015, p. 84) med at spørsmålet om nye studenter er forberedt til studier, ikke kan sees uavhengig av hvordan høyere utdanning tar imot studentene. Elevenes tekstkyndighet må videreutvikles gjennom undervisning og veiledning i en studiesammenheng, i nye kontekster og fagspesifikke diskurser (Greek \& Jonsmoen, 2016; Jonsmoen \& Greek, 2017). Tekstarbeidets ulike elementer som blant annet oppstart, lesing, utvelgelse, struktur og formuleringer, henger nøye sammen og påvirkes av ens selvtillit som skriver, graden av faglig kunnskap og metakunnskap om egne og andres tekster. Et sentralt spørsmål er derfor om nye studenter i høyere utdanning får den støtten som er nødvendig for å bygge videre på sine kunnskaper og ferdigheter slik at de videreutvikler sin tekstkyndighet.

\section{Studenters tekstkyndighet}

Forskning viser at svenske studenter ikke ser sammenhengen mellom skriving i videregående skole og studier (Ask, 2007). Tilsvarende resultater finner vi Norge. I studien «Skrivetradisjoner og utdanning - å skrive seg til profesjonsutøvelse» fulgte vi studieåret 2010/2011, 44 tilfeldig valgte studenter fra tre ulike bachelorutdanninger, i deres arbeid med skriftlige oppgaver gjennom første studieår. Hva tenker de om seg selv som skrivere, hvilke utfordringer møter de, hva er god veiledning for dem og ikke minst, hva mener de at de lærer ved å arbeide skriftlig med det faget de studerer? Informantenes skrivehistorier ga innblikk i deres personlige skriveprosess og hvordan de opplevde krav knyttet til ulike obligatoriske, skriftlige oppgaver. Sammen med informantene diskuterte vi ulike tekster de hadde skrevet. Funnene fra studien viser at studentene ikke stoler på at det de har med seg fra videregående skole er relevant $\mathrm{i}$ høyere utdanning (Jonsmoen \& Greek, 2012a). Studien viser også at studentene vektlegger form mer enn innhold. Både kravene til oppgaveskriving og språket som benyttes, oppleves som nytt for dem, og de ønsker mer kunnskap om hva en faglig argumentasjon er. Selv om studentene fikk mye skrivetrening i løpet av første studieår, var de ved slutten av året fortsatt usikre på hva som krevdes faglig og tekstlig. Det samme gjelder for studenter i tredje studieår (Greek \& Jonsmoen, 2013). Studentene er usikre på hvordan de kan innfri kravene studiet stiller til fagskriving og savner kunnskap om hvordan de skal argumentere i faget (Greek \& Jonsmoen, 2013). Også i tredje studieår er studentene mer opptatt av hvordan de skal skrive enn hva de skal skrive om.

I forbindelse med et pedagogisk utviklingsarbeid ved et helsefaglig profesjonsstudium fulgte vi i perioden 2014 - 2017 studentenes arbeid med bacheloroppgaven (Jonsmoen \& Greek, 
Manuscript in preparation). I bacheloroppgaven skal studentene «utforske teoretiske og kliniske problemstillinger på en systematisk og reflektert måte». De skal «planlegge, gjennomføre og dokumentere et prosjekt i tråd med retningslinjer for forskningsetikk og personvern» og «dokumentere skriftlig fagformidling etter vitenskapelige kriterier» (Programplan for det aktuelle bachelorstudiet 2017). Det aktuelle studieprogrammet har høye inntakskrav, noe som kan indikere «skoleflinke» studenter. Alle studentene fikk tilbud om tre skriveseminarer i tilknytning til sitt arbeid med bacheloroppgaven. Seminarene tok utgangspunkt i hvor studentene var i skriveprosessen og fulgte deres progresjon fra problemformulering mot ferdig tekst. I skriveseminarene ble arbeidet med studentenes egne tekster. Temaene som ble tatt opp i seminarene var utvikling av problemstilling, overordnet struktur og argumentasjon. Rundt en tredjedel av studentene på kullet, deltok på skriveseminarene.

Analyser av tekster og observasjoner i klasserommet viser at studentene har sjangerforståelse, høy grad av revisjonskompetanse og mestrer å se egne og andres tekster i et metaperspektiv. Likevel er de i likhet med elevene i videregående skole (Greek \& Jonsmoen 2016; Jonsmoen \& Greek 2016, 2017), førsteårsstudentene (Jonsmoen \& Greek, 2012a, 2012b) og andrespråksstudentene (Greek \& Jonsmoen 2013) mest opptatt av tekstens formside. Retningslinjene for bacheloroppgaven får stor oppmerksomhet. Studentene vil ikke «gjøre feil», noe som blant annet resulterer i at de lett mister fokus og glemmer egen problemstilling $\mathrm{i}$ iveren etter å innfri formkravene. Til tross for at de er i sitt siste år som bachelorstudenter og har fått veiledning underveis og i etterkant av sine mange skrivearbeider, viser de stor usikkerhet angående hvilken fagkunnskap som skal med i teksten og hvordan fagkunnskapen skal anvendes i argumentasjonen. De etterspør fortsatt en forklaring på hva en faglig overbevisende argumentasjon kan være og hvordan skrive en argumenterende tekst. De foreløpige resultatene samstemmer med annen forskning som viser at studenter er misfornøyd med den veiledningen de får, til tross for at lærerne erkjenner sitt ansvar for å støtte studenter gjennom veiledning (Prøitz, Hovdhaugen, \& Aamodt, 2015). Studentene vil ha konstruktive tilbakemeldinger og konkrete forklaringer på hva og hvordan, tilbakemeldinger som gjør dem til bedre skrivere og hjelper dem til økt faglig forståelse. Spørsmålet er hvem som best kan hjelpe dem med det og hva som er god skriveveiledningspraksis?

\section{En helhetlig skriveopplæring}

På bakgrunn av nevnte studier vil vi hevde at et systematisk og helhetlig veiledningstilbud i fagskriving for studenter krever at veiledere som gir skriveundervisning og -veiledning i og utenfor det enkelte studieprogrammet, selv har relevant tekstkyndighet og veiledningskompetanse og at de har kjennskap til studentenes forkunnskaper. Veilederne må dessuten ha forståelse for sin rolle og hva de skal veilede i for å bidra til at studentene videreutvikler sin tekstkyndighet. Det er lite kunnskap om tekstkompetanse blant veiledere i høyere utdanning i Norge. I 2012 gjennomførte vi en casestudie som så på tekstkompetansen til fagveiledere ved en norsk helsefaglig profesjonsutdanning (Jonsmoen \& Greek, 2012b), men vi kjenner ikke til forskning som ser på hvilken tekstkyndighet og veiledningskompetanse blant bibliotekarer og eksterne skrivepedagoger. Ut fra den kunnskap vi har per i dag, framstår tekstveiledningen $\mathrm{i}$ høyere utdanning som fragmentert og i liten grad preget av systematisk planlegging. Aktørene har forskjellig agendaer, de har ulik fagkunnskap, ulike faglige perspektiv og tilhører ulike tekstkulturer. Dersom budskapet deres ikke er samstemt, vil det kunne forvirre en allerede usikker student ytterligere.

Studentene $\varnothing$ nsker å gjennomføre studiet med gode resultater og er opptatt av å tilpasse seg de kravene som stilles. Lærerens hovedfokus er å formidle fagkunnskap, kunnskap som 
studentene skal dokumentere i ulike oppgaver underveis i studiet. Den profesjonelle yrkesutøveren som studentene møter i sine praktiske studier, er opptatt av praktisk kunnskap og yrkesspesifikke sjangre. Bibliotekaren bidrar med litteraturs $\emptyset \mathrm{k}$ og kildehåndtering ut fra sitt perspektiv. Skrivepedagogene har gjerne fokus på generiske trekk ved fagskriving. Ingen av veilederne er overflødige. Alle yter viktige bidrag i studentenes skriveprosess. Skal de ulike tilbudene om skriveveiledning og -undervisning føre til et godt læringsutbytte for den enkelte student, må imidlertid tilbudene utfylle hverandre og sammen gi et innhold som er relevant for det faget studentene studerer og tilpasset studentenes nivå. Det fordrer at de ulike veilederne samarbeider og er inneforstått med og enig i innholdet i hverandres tilbud. Målet må være å gi studentene en helhetlig og systematisk veiledning i skriving innen fagdisiplinen og ut fra studentenes behov, slik at skriveveiledningen blir effektiv og bidrar til forståelse for fagdisiplinens ulike sjangre.

God tekstveiledning avhenger av en samlet og bevisst plan for hva de ulike veilederne skal vektlegge i studentenes studieløp, og når det er hensiktsmessig. Veiledningen må inngå i et systematisk utviklingsløp der studentene lærer å skrive for studier og framtidig yrkesutøvelse. Studentene etterlyser skrivekurs og ber om kurs uten å være klar over hva de egentlig trenger, og kanskje er de, der og da, fornøyd med korte skrivekurs. Men studentene utvikler ikke skriveferdighetene sine i løpet av noen timer eller ved at noen forteller dem hvordan de skal skrive. Dysthe, Hertzberg og Hoel (2010) sammenlikner skriving med å spille piano. De skriver at du lærer ikke «å spille piano gjennom å lytte til flinke pianister. Men har du grunnferdighetene på piano, kan du lære mye som kan hjelpe deg til å bli en bedre pianist, gjennom å lytte til mestrene»(p. 17). Effektiv veiledning er heller ikke å gi studentene informasjon om litteraturs $\varnothing \mathrm{k}$ og studieoppgaver med krav til vitenskapelighet $f \phi r$ de har opparbeidet faglig forståelse, eller å tilby kurs i EndNote $f \emptyset r$ studentene har begynt å lese sekundærlitteratur eller begynt å skrive en oppgave som krever mer enn fire til fem referanser.

Lærerne forventer at studentene kan argumentere faglig for sine synspunkter. I norsktimene på videregående skole ble det arbeidet mye med drøfting (Greek \& Jonsmoen, 2016), men å drøfte i en studiesammenheng er mer komplisert. Det krever både dybdekunnskap i faget og sjangerforståelse. Studenter har derfor behov for mer enn enkle instruksjoner på nett, i bøker og på korte kurs. På en internettside for studenter blir det å drøfte forklart på følgende måte: «Få frem ulike synspunkter på emnet, begrunne egne synspunkter, se disse $\mathrm{i}$ forhold til hverandre og trekk konklusjoner» (Høgskolen i Oslo og Akershus, 2015). Forklaringen er forenklet og upresis, og avleder flere spørsmål enn svar. Hva betyr det å «[f]å frem ulike synspunkter på emnet»? Hvem sine synspunkter er det snakk om, og hvordan skal synspunktene presenteres? Det står at studentene skal "begrunne egne synspunkter", men det sies ikke hva studentene skal ha synspunkter på. Studentene skal dessuten «se disse [egne synspunkter] i forhold til hverandre», mens en oppgavebesvarelse i høyere utdanning vanligvis krever at studentenes egne synspunkter relateres til teori. Det er heller ikke vanlig at studentene skal trekke konklusjoner ut fra egne synspunkter, derimot skal eventuelle konklusjoner trekkes på bakgrunn av teori og empiri. Forklaringen som gis på nettet er uklar og kan bidra til økt forvirring. Studentene trenger grundigere og mer presise forklaringer, og de må vises hvordan de kan skrive, blant annet hvordan de konkret kan bruke andres tekster inn i eget skrivearbeid.

Studentene vet at de skal være redelige, og fra videregående skole er de vant til å referere til kilder i henhold til ulike referansesystemer. Men det er ikke ensbetydende med at de kan anvende kilder i egen argumentasjon slik at referansene bidrar til holdbare argumenter som viser faglig innsikt. Det studentene først og fremst har behov for når det gjelder kildebruk, er å lære hvordan de skal anvende kildene. Det fordrer at de arbeider grundig med kildene, kjenner 
forfatterens hovedsynspunkt(er) og faglige ståsted, og forstår fagstoffet så godt at de kan uttrykke det på en presis og relevant måte i egen tekst. Det krever lite å ramse opp en rekke forfattere på denne måten:

Det er forsket mye på elevers tekstarbeid i norsk vgs. (Askeland \& Aamotsbakken, 2012; Askeland \& Aamotsbakken 2013a; Askeland \& Aamotsbakken, 2013b; Gourvennec, Nielsen, \& Skaftun, 2014; Helstad \& Lund, 2012; Helstad \& Herzberg, 2013; Penne, 2012, 2013; Rødnes 2011; Rødnes \& Ludvigsen, 2009; Øgreid \& Hertzberg, 2009; Østren, 2008). (Konstruert eksempel fra artikkelforfatterne)

Eksemplet ovenfor viser kanskje at en har lest, eller i alle fall kjenner til at disse forfatterne beskjeftiger seg med elevers tekstarbeid. Men hvor dypt stikker kunnskapen? Teksten blir overfladisk og gir ikke leseren en forståelse av hva innenfor tekstarbeid forfatterne er opptatt av. Studentene i tredje år som deltok i det nevnte pedagogiske utviklingsarbeidet (Jonsmoen \& Greek, Manuscript in preparation), var usikre på hvordan de skulle anvende andres tekster i sin bacheloroppgave. Det de etterspurte var «hvordan referere», mens det de trengte hjelp til var å anvende kildene som for eksempel på denne måten:

Det er forsket mye på elevers tekstarbeid i norsk vgs. Det er gjennomført prosjekter som tar for seg skriving i og på tvers av fag (Askeland \& Aamotsbakken, 2012; Helstad \& Herzberg, 2013; Helstad \& Lund, 2012) og hvilke utfordringer elevene møter når de skriver (Askeland \& Aamotsbakken 2013a; Øgreid \& Hertzberg, 2009; Østren, 2008). Elevers tolkning av litterære tekster er godt dokumentert (Askeland \& Aamotsbakken, 2013b; Penne, 2012, 2013; Rødnes 2011), likeså hvordan elever arbeider seg fram til denne tolkninga (Rødnes \& Ludvigsen, 2009; Gourvennec, Nielsen, \& Skaftun, 2014). (Greek \& Jonsmoen, 2016, s. 256)

Solide fagtekster er kunnskapsrike, saksorienterte, argumenterende og presise. For å kunne føre en overbevisende argumentasjon i et fag må en ifølge Wingate (2012a), forstå det komplekse i saksforholdet, de faglige tekstkravene og bruke kildene kritisk. Det fordrer at fagskriveren leser fagspesifikke tekster og har et blikk for hvordan disse tekstene er skrevet, hva som er faglig sentralt og hvordan den faglige argumentasjonen føres. Det må læres. Studenten må sammen med lærere og andre veiledere diskutere både tekstenes form- og innholdsside. Studentene må få tilbakemelding på det de skriver og bearbeide tekstene om og om igjen. Til grunn for det hele må studenten forstå konteksten skrivinga inngår i. Skal studenter lære seg å skrive godt, må de skrive mye, og både de og veilederne deres må sette av tid til tekstarbeid. Dessuten må de ulike veilederne ha samme agenda. Lærere og andre veiledere må rett og slett samarbeide om studentenes skriving.

Forskning har gitt oss kunnskap om hvordan skriveveiledning i høyere utdanning kan bidra til tekstkyndighet og hvilket grunnlag veiledningen kan bygge videre på (Greek \& Jonsmoen, 2013, 2016; Hoel, 2008b; Hunter \& Tse, 2013; Jonsmoen \& Greek, 2012a, 2012b, 2016, 2017; Wingate \& Tribble, 2012). For å kunne bidra til utvikling av studentenes tekstkyndighet må som nevnt, veilederen ha kjennskap til studentenes forberedthet og faktiske behov, kunnskap om tekstkulturen i faget og ord og begreper til å snakke om tekster med studentene. Studentene er studieforberedt, men studieforberedt er ikke ensbetydende med mestring. For å kunne skrive velfungerende fagtekster, må studentene lære å studere faglitteratur, lete etter det sentrale i tekstene og skape mening og relevans for seg selv. Det fordrer at studentene gjenkjenner og forstår argumentasjonen og kan omformulere kunnskapen med egne ord. Har ikke studentene faglig forståelse for et tema, kan de heller ikke skrive godt om det. Det samme gjelder for veilederen. Uten kunnskap om faget, kan veiledningen føre til at det hovedsakelig er språk og formalia som vektlegges, noe som i verste fall kan føre til at en 
tekst som er faglig grunn får en språklig polering som skjuler mangelen på faglig innhold. Å skjule tekstens mangel på faglig innhold og dybde, er kanskje like ille som slapp kildehåndtering. En veileder skal først og fremst å ta innholdet på alvor. Den nærmeste til å veilede studentene i fagskriving er dermed læreren som kjenner faget, sjangrene i faget og pensumlitteraturen (Wingate, 2012a, 2012b).

Wingate et al. (2011) viser i en casestudie hvordan arbeid med lesing og skriving med hell kan integreres i ordinær undervisning. Studentene som deltok i studien, fikk oppgaver som ga dem et fokus for lesinga, hjalp dem til å finne tekstens hovedpoeng og argumentasjon og som var en støtte da de skulle ta notater. I etterkant av forelesninger og undervisning ble relevante problemstillinger diskutert, og studentene måtte oppsummere diskusjonen skriftlig. Lærer gikk også igjennom eksempler på forskningslitteratur og vektla argumentasjon, språk, stil og bruk av referanser.

Ved å vise studentene hvordan en selv leser en vitenskapelig artikkel eller en annen fagtekst og ved å analysere tekstene sammen med studentene, bidrar læreren til fagtilegnelse samtidig som studentene utvikler tekstkyndighet. Diskusjoner om tekstoppbygging og tekstelementenes ulike funksjoner, hvordan argumentasjon føres og hvordan slutninger tas, gir studentene anledning til å bruke og videreutvikle tekstkyndigheten de har med seg fra videregående skole. Etter hvert vil studentene selv finne mønstre å følge i fagdisiplinens tekster. Imidlertid har ikke alltid en lærer den kunnskapen og det språket som er nødvendig for å snakke om tekster med studentene. Det er det skrivepedagogen som har. Den optimale løsningen vil være et samarbeid mellom læreren og skrivepedagogen, slik at læreren opparbeider seg et blikk og et språk for tekstanalyse og metoder til bruk i sin tekstveiledning (Hunter \& Tse, 2013; Jonsmoen \& Greek, 2012b; Wingate, 2012b). I tillegg bør bibliotekaren bidra med sin kunnskap gjennom et samarbeid med både lærer og skrivepedagog.

\section{Måloppnåelse fordrer innsats}

Studentene $\emptyset$ nsker høye karakterer, og veilederne $\emptyset$ nsker at studentene skal lykkes. Men er både studentene og deres veiledere villige til å gjøre det som skal til for at måloppnåelsen skal finne sted? Mange års erfaring med å holde skrivekurs i høyere utdanning forteller at få studenter deltar på skrivekurs utenom ordinær undervisning. For det første er det få som møter opp, for det andre er det få som på forhånd sender inn egne skrivearbeider til bruk i kursene, og for det tredje kvier studentene seg for å skrive i skrivekursene. Studentene vil gjerne at noen skal fortelle dem hvordan de skal skrive uten at de selv trenger å skrive. Men skal studentene skrive fagtekster av verdi, må de først og fremst ha kunnskap. Det krever at de leser, forstår faget og utdanningens krav. Dernest må de trene på å skrive, de må skrive mye og de må bearbeide de tekstene de skriver. $\AA$ skrive solide fagtekster er et møysommelig arbeid. Det krever systematikk, innsikt i egen skriveprosess, utholdenhet og tålmodighet.

Å kunne tilby studentene skriveveiledning som holder høy kvalitet, krever både kunnskap og samarbeid. Veilederne bør blant annet komme sammen for å $ø$ ke sin kunnskap om ulike tekstkulturer og opparbeide seg et felles begrepsapparat med utgangspunkt $\mathrm{i}$ det begrepsapparatet studentene allerede har med seg fra videregående skole. Den enkelte veileder, enten det er lærer, skrivepedagog eller bibliotekar, må utvikle evnen til å ta et metaperspektiv på ulike fagtekster og et språk for å snakke om tekster (Jonsmoen \& Greek, 2016). Studenter har behov for å delta i samtaler om tekst som synliggjør den rådende tekstkulturen og de kravene som stilles til fagskriving i studiet. Bibliotekarene kan veilede studentene i søk, kildekritikk, EndNote og referansestiler, men når det kommer til det å veilede studenter $\mathrm{i}$ arbeidet med å 
formulere setninger og bygge opp en argumentasjon innen et spesifikt fagdomene, er ikke det vanligvis bibliotekarenes spesialfelt. Det må i så fall læres. Det er dessuten relevant å spørre om veilederne selv skriver tekster som drøfter faglige problemstillinger. Uten et relevant metaspråk og egen skriveerfaring blir det vanskelig å veilede studenter i deres skriveprosess. Som skrivepedagogene, har bibliotekarene, om de ikke selv har studert faget, lite kunnskap innenfor fagspesifikke temaer og om fagdisiplinenes tekstkultur. Men de har viktig kunnskap som bør inngår i enhver faglig skriveprosess, blant annet litteratursøk og kildekritikk. Dette er kunnskap lærerne trenger i sin skriveveiledning. Ettersom skriving er en del av faget, bør kanskje lærerne være bibliotekarenes og skrivepedagogenes primære målgruppe.

\section{Konklusjon}

På samme måte som det står i programplanene at studentene etter endt utdanning skal kunne tilegne seg og gjøre bruk av ny forskningsbasert kunnskap, må også veilederne gjøre det. Skriveveiledning skal være basert på fakta og ikke styrt ut fra veiledernes kompetanse og forestillinger om studentenes behov eller hva fagskriving er. Bibliotekarer og skrivepedagoger er en del av støtteapparatet rundt lærerne og bør ideelt sett bistå lærerne med nødvendig kunnskap, slik at lærerne kan gi studentene den kompetansen de trenger for å skrive tekster som innfrir fagdisiplinens krav. Den største utfordringen er å få alle som veileder og underviser studentene i deres skrivearbeider til å komme i dialog med hverandre, slik at en helhetlig skriveveiledning for studier og profesjon kan bli en realitet. En helhetlig skriveveiledning fordrer at de skrivearbeidene studentene får, sees i sammenheng, og at de ulike veilederne diskuterer hva studentene skal lære når. Når bør en begynne å tematisere lesing i studiet, når skal en presentere og forklare krav til studenttekster, når skal studentene få mer kunnskap om litteratursøk og når er det lurt å ta i bruk EndNote? På hvilken arena skal lærere, skrivepedagoger og bibliotekarer møtes? Det spesifikke studiet er arenaen, og derfor bør initiativet til samarbeid komme fra lærerne. Men om kontakten uteblir, kan bibliotekarer og skrivepedagoger nå lærerne i kjente kanaler der flere av aktørene allerede er representert slik som for eksempel i forskergrupper. Dessuten bør skriveveiledning være et av temaene i universitet- og høyskolepedagogikk. Vi etterspør altså en diskusjon omkring spørsmålet når skal studentene lære hva av hvem:

- Hvem skal lære studentene å lese faglitteratur?

- Hvem skal lære studentene å skrive innen fagdisiplinen?

- Hvem skal bidra til at studentene utvikler et kritisk analytisk faglig blikk?

- Hvem skal lære studentene å søke litteratur innen fagdisiplinen?

- Hvem skal lære studentene kildebruk og referansesystemer?

- Hvem skal lære studentene EndNote?

- Og når skal det skje?

Vi konkluderer med at høyere utdanning bør tilby studentenes ulike veiledere kompetanseheving knyttet til studenters tekstarbeid. Inspirasjon, metoder og begrepsapparat kan hentes fra videregående skole. Om videregående skole og høyere utdanning tar hverandre i betraktning i sin pedagogiske planlegging og i større grad tenker læring som en prosess som fortsetter etter eventuelle eksamener, vil trolig det eksisterende gapet mellom skoleslagene, og mellom ulike studieprogram minske. Vi håper derfor at det $\mathrm{i}$ framtida igangsettes flere 
forsknings- og utviklingsprosjekter som ser på hvordan lærere, bibliotekarer og skrivepedagoger i høyere utdanning sammen kan styrke studentenes tekstkyndighet.

\section{Referanser}

Ask, S. (2007). Vägar till ett akademiskt skriftspråk. Acta Wexionesia nr. 115/2007

Dysthe, O., Hoel, T. L., \& Hertzberg, F. (2010). Skrive for å lare : skriving i høyere utdanning (2. utg. ed.). Oslo: Abstrakt.

Greek, M., \& Jonsmoen, K. M. (2013). Skriveveiledning til økt fag- og tekstforståelse. Norsk pedagogisk tidsskrift, 97(04-05), 281-290.

Greek, M., \& Jonsmoen, K. M. (2016). Hvilken tekstkyndighet har studenter med seg fra videregående skole? Uniped (03), 255-270.

Hertzberg, F., \& Roe, A. (2016). Writing in the content areas: a Norwegian case study. Reading \& Writing, 29(3), 555-576. https://doi.org/10.1007/s11145-015-9607-7

Hoel, T. L. (2008a). Skriving ved universitet og høgskolar : for laerarar og studentar. Oslo: Universitetsforlaget.

Hoel, T. L. (2008b). Jeg skriver, altså er jeg: om skriving i profesjonsutdanninger. Tekst som flytter grenser (130-143, Oslo: Novus Forlag.

Hunter, K., \& Tse, H. (2013). Making disciplinary writing and thinking practices an integral part of academic content teaching. Active Learning in Higher Education, 14(3), 227239. https://doi.org/10.1177/1469787413498037

Jonsmoen, K. M., \& Greek, M. (2012a). "Hodet blir tungt - og tomt" ; om det å skrive seg til profesjonsutøvelse. Norsk pedagogisk tidsskrift.

Jonsmoen, K. M., \& Greek, M., (2012b). Skrivekår i profesjonsutdanning. Uniped, 3(04), 413.

Jonsmoen, K. M. \& Greek, M, (2016). Lecturers' text competencies and guidance towards academic literacy. Educational Action Research, 1-16. https://doi.otg/10.1080/09650792.2016.1178156

Jonsmoen, K. M., \& Greek, M. (2017). På stø kurs inn i akademia? NOA nr. 1, 2017.

Jonsmoen, K. M., \& Greek, M. (Manuscript in preparation). Studentens skriveprosess $i$ arbeidet med Bacheloroppgaven.

Lindberg, Y., \& Sandblom, E. (2013). Blivande svensklärare skriver argumenterande text. In D. Skjelbred \& A. Veum (Eds.), Literacy i laeringskontekster (pp. 264-281). Oslo: Cappelen Damm.

Lødding, B., \& Aamodt, P.O. (2015). Studieforberedt etter studieforberedende. Overgangen mellom studieforberedende utdanningsprogram og hфyere utdanning belyst gjennom gruppesamtaler med laerere, studenter og elever. NIFU-rapport 2015:28. NIFU. Oslo.

Penne, S. (2013). Skjønnlitteraturen i skolen i et literacy-perspektiv. In D. Skjelbred \& A. Veum (Eds.), Literacy i lacingskontekster (pp. 42-54). Oslo: Cappelen Damm.

Prøitz, T. S., Hovdhaugen, E., \& Aamodt, P. O. (2015). Tilbakemeldinger i høyere utdanning : hva sier studenter og lærere. In N. Frølich (Ed.), Hva skjer i universiteter og høgskoler? Perspektiver fra vitenskapelig ansatte og studenter (pp. s. 37-50). Oslo: Universitetsforl., 2015.

Rienecker, L., \& Stray Jørgensen, P. (2013). Den gode oppgaven : håndbok i oppgaveskriving på universitet og høyskole (2. utg. ed.). Bergen: Fagbokforl.

Samara, A., \& Dysthe, O. (2006). Forskningsveiledning på master- og doktorgradsnivå. Oslo: Abstrakt.

Sivesind, K. (2013). Læreplanene i Kunnskapsløftet: et internasjonaltsammenliknende perspektiv. Norsk pedagogisk tidsskrift, 97(06), 370-387. 
Skjelbred, D. (2012). "Elevaktivitetens prinsipp" og oppgaver i lærebøker. In S. Matre, D. Kibsgaard Sjøhelle \& R. Solheim (Eds.), Teorier om tekst i møte med skolens lese- og skrivepraksiser (pp. 175-186). Oslo: Universitetsforl.

Skjelbred, D., \& Veum, A. (2013) Innledning - Literacy i læringskontekster. In Skjelbred, D., \& Veum, A. (Eds.), Literacy i laeringskontekster (pp. 11-25) Oslo: Cappelen Damm.

St.meld. nr. 27 (2000-2001) (2001). Gjфr din plikt-Krev din rett: Kvalitetsreformen av hфyere utdanning. Det kongelige kirke-, utdannings- og forskningsdepartement.

Utdanningsdirektoratet. (udatert a). Lareplan i norsk. Retrieved from http://www.udir.no/k106/NOR1-05/Hele/Hovedomraader/.

Utdanningsdirektoratet. (udatert b). Kompetansemål etter Vg3 - studieforberedende utdanningsprogram. Retrieved from https://www.udir.no/k106/NOR105/Hele/Kompetansemaal/kompetansemal-etter-vg3-\%E2\%80\%93-studieforberedendeutdanningsprogram.

Wingate, U. (2012a). 'Argument!' helping students understand what essay writing is about. Journal of English for Academic Purposes, 11(2), 145-154. https://doi.org/10.1016/j.jeap.2011.11.001

Wingate, U. (2012b). Using Academic Literacies and genre-based models for academic writing instruction: A 'literacy' journey. Journal of English for Academic Purposes, 11(1), 26-37. https://doi.org/10.1016/j.jeap.2011.11.006

Wingate, U., Andon, N., \& Cogo, A. (2011). Embedding academic writing instruction into subject teaching: A case study. Active Learning in Higher Education, 12(1), 69-81. https://doi.org/10.1177/1469787410387814

Wingate, U., \& Tribble, C. (2012). The best of both worlds? Towards an English for Academic Purposes/Academic Literacies writing pedagogy. Studies in Higher Education, 37(4), 481-495. https://doi.org/10.1080/03075079.2010.525630

Øgreid, A., \& Hertzberg, F. (2009). Argumentation in and Across Disciplines: Two Norwegian Cases. An International Journal on Reasoning, 23(4), 451-468. https://doi.org/10.1007/s10503-009-9162-y 